\title{
The Effect of Charlson's Comorbidity Index on Clavien-Dindo Classification of Surgical Complications in Percutaneous Nephrolitotomy
}

\section{Perkütan Nefrolitotomide Charlson Komorbidite Indeksi'nin Postoperatif Clavien Komplikasyon Skalası Üzerine Etkisi}

\author{
Reha Girgin1, Ramazan Topaktaș1, Selçuk Altın1, Cemil Aydın1, Ali Akkoç1, Bülent Akduman2 \\ 1Diyarbakır Gazi Yaşargil Training and Research Hospital, Clinic of Urology, Diyarbakır, Turkey \\ 2Bülent Ecevit University Faculty of Medicine, Medical Faculty Hospital, Clinic of Urology, Zonguldak, Turkey
}

\begin{abstract}
What's known on the subject? and What does the study add?
In this series the remarkable feature is that about $50 \%$ of patients had various comorbidities. Advanced age and comorbidity makes patients more susceptible to surgical complications. In this study, achievement similar complication rate between the groups suggest that the presence of preoperative comorbidities do not create a major risk factor on com.
\end{abstract}

\section{ABSTRACT}

Objective

Percutaneous nephrolithotomy (PCNL) in comorbid patients is challenging due to the high susceptibility to complications. In our study, by taking the age of patents into account, we have tried to figure out the impact of comorbid conditions on complications identified after PCNL operations in our clinic.

\section{Materials and Methods}

Three hundred-sixty patients, who underwent PCNL in our clinic between June 2002 and June 2012, were retrospectively analyzed. The patients were assessed in terms of demographic characteristics, access locations, preoperative comorbidity using the age-adjusted Charlson's Comorbidity Index (ACCI) and postoperative complications using the Clavien-Dindo classification of surgical complications.

Results

The mean age of the patients was 46 (10-83) years. Two hundred-twenty $(61.1 \%)$ patients were male and $140(38.9 \%)$ were female. According to preoperative $\mathrm{ACCl}, 169$ (46.9\%) of the cases were classified as group 1 and $191(53.1 \%)$ of the cases as group 2. In 212 (58.8\%) patients, entry into the lower calyx, in $136(37.7 \%)$ - into the middle calyx and in $12(3.3 \%)$ patients, entry into the upper calyx was done. The rate of complications in ACCl group 1, grade 1, grade 2 and grade 3a was 12.4\%, 18.9\%, 8.28\% and in group 2, it was $6.8 \%, 26.7 \%, 6.28 \%$, respectively. There was no significant difference between the groups $(p=0.098, p=0.16$ and $p=0.49$, respectively). Grade $3 \mathrm{~b}$ and grade $4 \mathrm{a}$ complications were seen only in

\section{öz}

Amaç

Perkütan nefrolitotomi (PNL), komorbiditesi olan hastalarda komplikasyonlara daha duyarlı olmaları nedeniyle zorludur. Bu çalışmada, kliniğimizde PNL operasyonları sonrası belirlenen komplikasyonlar üzerinde eşlik eden durumların etkisini hastaların yaşlarını da dikkate alarak dikkate alarak incelemeye çalıştık.

\section{Gereç ve Yöntem}

Haziran 2002 ve Haziran 2012 tarihleri arasında kliniğimizde, PNL uygulanan 360 hasta retrospektif olarak incelendi. Bu çalışmada hastalar, demografik özellikleri, akses giriş yerleri, yaşa göre düzeltilmiş Charlson Komorbidite İndeksi'ne (ACCI) göre preoperatif komorbiditeleri ve Clavien-Dindo Sınıflandırma Sistemi kullanılarak gelişen postoperatif komplikasyonları açısından değerlendirildi.

Bulgular

Çalışmaya alınan 360 hastanın yaş ortalaması 46 idi (10-83 yıl). Hastaların 220 'si $(\% 61,1)$ erkek ve 140'ı $(\% 38,9)$ kadındı. ACCl sınıflamasına göre hastaların 169'u $(\% 46,9)$ grup 1 ve 191'i $(\% 53,1)$ grup 2 olarak tanımlandı. Olguların 212'sine $(\% 58,8)$ alt kaliks, 136 'sına $(37,7 \%)$ orta kaliks ve 12 'sine $(3,3 \%)$ de üst kaliks girişi uygulandı. Komplikasyonlara bakıldığında ACCI grup 1 hastalarda \%12,4 sınıf 1, \%18,9 sınıf 2, \%8,28 sinıf 3a ve ACCI grup 2 hastalarda \%6,8 sinıf 1, \%26,7 sinıf 2, \% 6,28 sınıf 3a komplikasyon görüldü $(p=0,098 ; 0,16 ; 0,49)$. Sınıf $3 b$ ve sınıf $4 a$ komplikasyonlar sadece ACCI grup 2 hastalarda görüldü. Sınıf $4 b$ ve 5 komplikasyon her iki grup hastalarda da görülmedi.

\section{Correspondence}

Reha Girgin MD, Diyarbakır Gazi Yaşargil Training and Research Hospital, Clinic of Urology, Diyarbakır, Turkey

Phone: +90 5378865912 E-mail: mujdereha@hotmail.com Received: 07.05.2016 Accepted: 11.05.2016 
group $2(1.04 \%, 0.52 \%$, resceptively). Grade $4 \mathrm{~b}$ and 5 complications were not observed in both groups.

\section{Conclusion}

Considering the age of patients, we have not observed a significant difference in the rate of postoperative complications between the groups. Therefore, we assume that the recognized preoperative comorbidities are not risk factors for PCNL procedures and operations.

\section{Keywords}

Percutaneous nephrolithotomy, the age-adjusted Charlson's Comorbidity Index, the Clavien-Dindo Classification of surgical complications

\section{Sonuç}

Biz hastaların yaşlarını da dikkate aldığımızda, ameliyat sonrası komplikasyon oranları arasında anlamlı bir fark gözlemlemedik. Bu nedenle, tanımlanmış preoperatif komorbiditelerin PNL işlemleri ve operasyonları için risk faktörleri olmadığını düşünmekteyiz.

\section{Anahtar Kelimeler}

Perkütan nefrolitotomi, yaşa göre düzeltilmiş Charlson Komorbidite Indeksi, Clavien-Dindo sınıflandırma sistemi

\section{Introduction}

Urinary tract stone disease is widely seen in our country occupying an important place in the practice of urology. It has been reported that $10 \%$ of people live with this disease throughout their lives (1). Treatment options for kidney stones include extracorporeal shock wave lithotripsy (ESWL), ureterorenoscopy, percutaneous nephrolithotomy (PCNL), and open and laparoscopic surgery. PCNL is a minimally invasive surgical procedure for the treatment of kidney stones. Since Rupel and Brown extracted an calculus via an operatively established nephrostomy in 1941, owing to the development of novel techniques and equipment through years, PCNL today has become a preferred method in the treatment of large-volume stones in cases where stone extraction is difficult for reasons depending on the anatomical structure or stone localization. The method is not completely innocent although overall success rate of $>90 \%$; it has been reported in the Clinical Research Office of the Endourological Society (CROES) PCNL Global Study that $20.5 \%$ of 5724 subjects $(n=1175)$ experienced one more complications $(2,3)$. Although extravasation (7.2\%), hemorrhage requiring blood transfusion (11.2-17.5\%) and fever (21-32.1\%) are common complications; septicemia (0.3-4.7\%), colon injuries (0.2-4.8\%) and pleural injury (\%0-3.1) are among the rare major complications (4). Conversion to open surgery is rare and is usually required during the first experience with PCNL (5). In PCNL operation, the reported mortality rate is between $0.3 \%$ and $0.046 \%$ (6).

In the literature, although there are studies investigating the effects of patients' co-morbid conditions on PCNL complications (4), there have been no study examining the effects of multiple co-morbid factors including patient age on complications.

In our study, taking into account patients' age, we discussed the relationship between complications and pre-existing comorbid conditions in patients undergoing PCNL operations in light of the literature.

\section{Materials and Methods}

Three hundred-sixty patients who underwent PCNL in our clinic between June 2002 and June 2012 were retrospectively analyzed. Written informed consent was obtained from all subjects. Demographic characteristics, preoperative comorbidity, preoperative and postoperative hemoglobin values, access locations, and intraoperative and postoperative complications were evaluated. Patients with a history of previous operations on the same side of the kidney, solitary kidney, PCNL made simultaneously on both kidney and those with operations with more than one access were excluded from the study. Preoperative comorbidities were obtained from hospital records and age-adjusted Charlson's comorbidity index (ACCI) scores were calculated by using the existing 19 comorbid parameters including the patients' age (Table 1) (7). The patients were divided into two groups according to their preoperative comorbidities as ACCI group 1 (0 points) and $\mathrm{ACCl}$ group 2 (points 1 and above). The protocol for this study was reviewed and approved by the Ethics Committee (Institutional Review Board) of the Faculty of Medicine, Bülent Ecevit University (date: 16/04/2013, meeting number: 2013/09, protocol number: 2013-49-16/04).

Two grams of ceftriaxone was given as prophylactic antibiotic in patients with negative urine cultures. Patients with positive urine culture were treated with antibiotics based on the antibiogram at least 48 hours before surgery. The percutaneous access was performed with the patient in the prone position following the contrast media injection via the open-ended ureteral catheter which was placed transurethrally in the supine position prior to the renal access. Both working and safety guide wires were inserted after successful access. Tract dilatations were performed by Amplatz fascial dilators until 30 Fr and Amplatz sheath was used in all cases. A standard nephroscope was used with pneumatic lithotripsy for stone disintegration. At the end of the procedure, $20 \mathrm{~F}$ nephrostomy tubes were inserted for 48 to 72 hours. All patients had postoperative direct urinary system graphy and laboratory investigation.

Postoperative complications were defined as adverse events occurred in 30 days and were graded by the Clavien-Dindo classification of surgical complications (CDCSC) that provides an objective and practical way to grouping complications (8). The complications were divided into 7 groups according to the classification $(1,2,3 a, 3 b$, $4 a, 4 b, 5)$. Underarm measurement of 37.5 degrees and above was evaluated as fever.

Statistical analysis was performed using SPSS version 19.0. Descriptive statistics for continuous variables were shown as mean and standard deviation and descriptive statistics of categorical variables were shown as frequency and percentage. Pearson's Chi-Square, Yates-corrected Chi-Square and Fisher's exact tests were used for comparison of categorical variables. 


\section{Results}

The average age of the 360 patients (220 (61.1\%) male and 140 (38.9\%) female) was 46 (10-83) years. According to preoperative ACCI, 169 (46.9\%) patients were classified as group 1 and 191 (53.1\%) as group 2. In 212 (58.8\%) patients, entry into the lower calyx, in 136 $(37.7 \%)$ - into the middle calyx, and in $12(3.3 \%)$ patients, entry into the upper calyx was done. The demographic characteristics of the patients and intra-postoperative findings are summarized in Table 2. All patients underwent standard PCNL under general anesthesia. In $40(11.1 \%)$ subjects intraoperative complications and in 50 (13.8\%), postoperative complications were observed.

In Table $3 \mathrm{ACCl}$ groups and scores CDCSC are compared. The most common complications were fever and mild bleeding (Table 4). Fourteen (3.8\%) of complications were due to surgery, 47 (13.0\%) were due to medical reasons. There was no significant difference in the complication rate though patients co-morbidity index (ACCI scores) increases. Minor complications as CDCSC grade 1 and 2 were seen in the foreground. Fever seen after operation, blood transfusion because of a fall in hemoglobin level as a result of surgical procedure, DJ catheter application secondary to extravasation because of surgeon, surgical procedure and stone burden were independent factors of comorbidities.

The relationship between complications and calyceal entry sides are described in Table 5 and 6.

In ACCI group 2 after the middle caliceal entry, in 1 case grade $3 b$ $(0.5 \%)$ and in 1 case grade $4 a(0.5 \%)$ complication has been seen that were not significant (Table 5). In 1 patient of ACCI group 1, after the upper caliceal entry, pneumothorax followed by deep vein thrombosis due to pulmonerthromboembolism was seen $(p=0.032$ ) (Table 6).

\section{Discussion}

Table 1. The age-adjusted Charlson's Comorbidity Index (7)

\begin{tabular}{|c|c|}
\hline Point & Comorbid conditions \\
\hline 1 & $\begin{array}{l}\text { Myocardial infarction } \\
\text { Congestive heart failure } \\
\text { Peripheral vascular disease } \\
\text { Cerebrovascular disease } \\
\text { Dementia } \\
\text { Chronic pulmonary disease } \\
\text { Connective tissue disease } \\
\text { Ulcers } \\
\text { Mild liver disease } \\
\text { Diabetes }\end{array}$ \\
\hline 2 & $\begin{array}{l}\text { Hemiplegia } \\
\text { Moderate/severe renal disease } \\
\text { Diabetes with end-organ damage } \\
\text { Any tumor } \\
\text { Leukemia } \\
\text { Lymphoma }\end{array}$ \\
\hline 3 & Moderate/severe liver disease \\
\hline 6 & $\begin{array}{l}\text { Metastatic solid tumors } \\
\text { AIDS }\end{array}$ \\
\hline 1 & Over 40 years for every decades \\
\hline
\end{tabular}

This study emphasizes that patients with kidney stones treated with PCNL also have preoperative comorbidities. In about half of patients, there are a variety of comorbidities. However, an increased comorbidity score does not show an increase in the rate of complications.

According to the American Urological Association and the European Association of Urology (EAU) guidelines on nephrolithiasis, ESWL is considered as the first-line treatment modality The main indications for PCNL include stones not responding to ESWL and stones especially over $2 \mathrm{~cm}$ in size and hard (cystine, COM) (9).

ACCl was created to estimate the long-term mortality and is a method to classify existing comorbid conditions (10). Charlson and colleagues have created a variety of disease categories and have identified certain points in each category. They gave 1 point to comorbid conditions, such as myocardial infarction, congestive heart

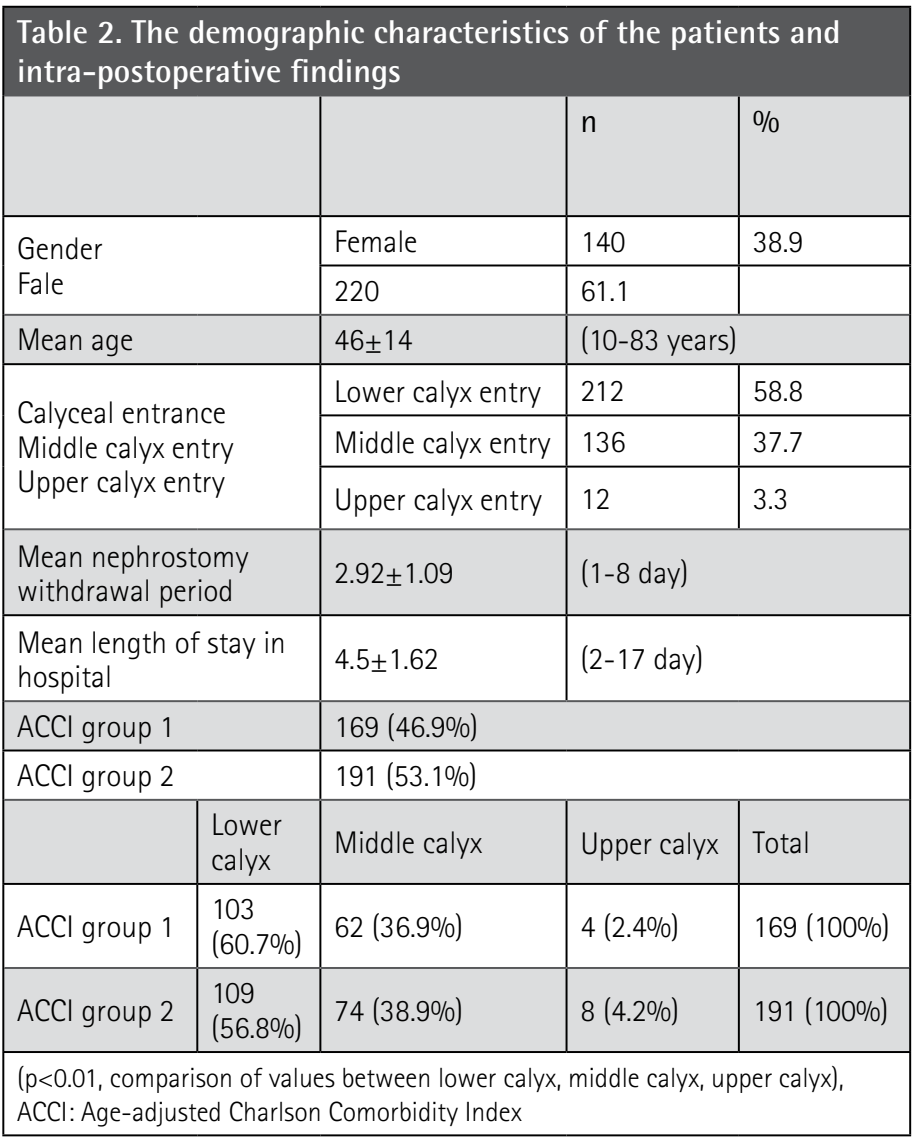

Table 3. Comparison of age-adjusted Charlson Comorbidity Index groups and Clavien-Dindo Classification of surgical complications

\begin{tabular}{|l|l|l|l|}
\hline CDCSC & $\begin{array}{l}\text { ACCl group 1 } \\
(n=169)\end{array}$ & $\begin{array}{l}\text { ACCl group 2 } \\
(n=191)\end{array}$ & $p^{*}$ \\
\hline Grade 1 & $21(12.4 \%)$ & $13(6.8 \%)$ & 0.098 \\
\hline Grade 2 & $32(18.9 \%)$ & $51(26.7 \%)$ & 0.16 \\
\hline Grade 3a & $14(8.28 \%)$ & $12(6.28 \%)$ & 0.49 \\
\hline Grade 3b & - & $2(1.04 \%)$ & NS $^{* *}$ \\
\hline Grade 4a & - & $1(0.52 \%)$ & $N^{* *}$ \\
\hline $\begin{array}{l}{ }^{*} p<0.05, \text { Chi-square tests, }{ }^{* *} \text { NS: Non specific, ACCI: Age-adjusted Charlson } \\
\text { Comorbidity Index, CDCSC: Clavien-Dindo Classification of Surgical Complications }\end{array}$ \\
\hline
\end{tabular}


failure, peripheral vascular disease, cerebrovascular disease, dementia, chronic pulmonary disease, connective tissue disease, ulcers, mild liver disease, and diabetes. The sum of all points of comorbid conditions constitute the final score (Table 1).

Geriatric population constitutes the fastest growing segment in many parts of the world. Although age itself is not a disease, but in elderly patients with reduced functional reserve of organs makes them more sensitive to stress factors, such as bleeding, sepsis and medical complications $(11,12)$. The effects of age on complications have been addressed in several studies $(13,14,15,16)$. Koppie et al. $(7)$, for the first time, formed the ACCl scores by including the patients' age to estimate the outcomes of patients who underwent radical cystectomy when calculating the Charlson's comorbidity index scores (Table 1).

In a retrospective series published by Sahin et al. (14), the complication rate of percutaneous nefrolitototmy operation in patients aged over 60 years has been reported to be similar to that in younger patients. Similarly, in a series published in 2012, Okeke and colleagues (15) have reported similar complication rates in younger patients compared to those in patients aged 70 years and older. Stoller et al. (13) have reported higher transfusion rates in elderly after PCNL. In their study published in 2012, Unsal et al (16) have reported that there was an increase in preoperative comorbidities and postoperative complications in parallel with age.

In this study, when patients were divided into two groups according to $\mathrm{ACCl}$ based on the preoperative comorbid conditions and taking into consideration the age, similar postoperative complication rates were observed between $\mathrm{ACCl}$ group 1 and $\mathrm{ACCl}$ group 2 .

Oner et al. (17) have reported in their study of 1750 cases that large stones, stone complexity, multi tract entry, lack of experience and a prolonged period of PCNL operations increased the rate of complications. Similarly, in a study of 2.318 subjects made by OlveraPosada et al. (18), it has been reported that older age and upper pole access were associated with an increased risk of major complications.

The pleura and the lungs are reported to be the most injured organs during PCNL operations especially in those via intercostal entry above the $12^{\text {th }}$ rib. Hopper and Yakes (19) in their series reported that intercostal entry made after full expiration was responsible for $86 \%$ of the pleura and 29\% of the lung injuries. In their series published in 2007, Sukumar et al. (20) assessed the success of supracostal

Table 4. Age-adjusted Charlson Comorbidity Index groups and Clavien-Dindo Classification of Surgical Complications were compared

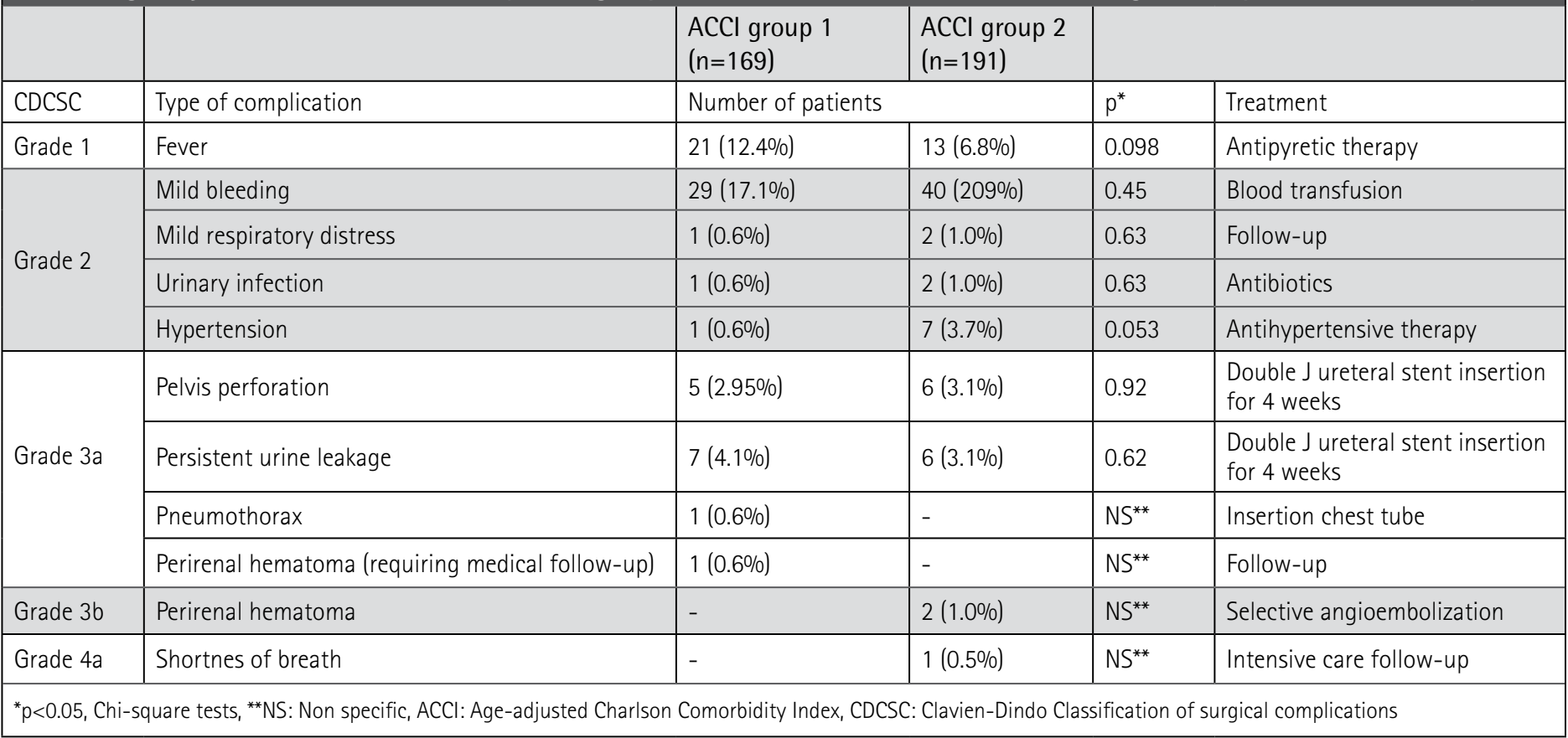

Table 5. Comparison of age-adjusted Charlson Comorbidity Index groups and Clavien-Dindo Classification of Surgical Complications According to the calyx of entry

\begin{tabular}{|c|c|c|c|c|c|c|c|}
\hline \multirow[b]{2}{*}{$\operatorname{CDCSC}$} & \multicolumn{3}{|c|}{$\begin{array}{l}\text { ACCl group } 1 \\
(n=169)\end{array}$} & \multicolumn{3}{|c|}{$\begin{array}{l}\text { ACCI group } 2 \\
(n=191)\end{array}$} & \multirow[b]{2}{*}{$p$} \\
\hline & Lower calyx & Middle calyx & Upper calyx & Lower calyx & Middle calyx & Upper calyx & \\
\hline Grade 1 & $16(9.5 \%)$ & $5(2.9 \%)$ & - & $8(4.2 \%)$ & $4(2.1 \%)$ & $1(0.5 \%)$ & 0.326 \\
\hline Grade 2 & 21 (12.4\%) & $11(6.5 \%)$ & - & 30 (15.7\%) & 19 (9.9\%) & $2(1.0 \%)$ & 0.347 \\
\hline Grade 3a & $7(4.1 \%)$ & $6(3.5 \%)$ & $1(0.6 \%)$ & $9(4.7 \%)$ & $3(1.6 \%)$ & - & 0.435 \\
\hline Grade 3b & - & - & - & $1(0.5 \%)$ & $1(0.5 \%)$ & - & - \\
\hline Grade 4a & - & - & - & - & $1(0.5 \%)$ & - & - \\
\hline
\end{tabular}


Table 6. Complications and statistical $p$ values according to the calyx of entry in all cases

\begin{tabular}{|l|l|l|l|l|}
\hline & $\begin{array}{l}\text { Lower } \\
\text { calyx }\end{array}$ & $\begin{array}{l}\text { Middle } \\
\text { calyx }\end{array}$ & $\begin{array}{l}\text { Upper } \\
\text { calyx }\end{array}$ & $p^{*}$ \\
\hline Mild respiratory distress & - & $3(2.2 \%)$ & - & 0.054 \\
\hline Hypertension & $4(1.9 \%)$ & $4(2.9 \%)$ & - & 0.626 \\
\hline Severe hematuria & $1(0.5 \%)$ & $1(0.7 \%)$ & - & 0.891 \\
\hline Fever & $\begin{array}{l}24 \\
(11.4 \%)\end{array}$ & $9(6.6 \%)$ & $1(8.3 \%)$ & 0.326 \\
\hline Perirenal hematoma & $1(0.3 \%)$ & $2(0.5 \%)$ & - & 0.725 \\
\hline Deep vein thrombosis & - & - & $1(0.5 \%)$ & 0.586 \\
\hline Pulmonerthromboembolism & - & - & $1(8.3 \%)$ & 0.032 \\
\hline Urinary infection & $1(0.5 \%)$ & $2(1.5 \%)$ & - & 0.569 \\
\hline Pneumothorax & - & - & $1(8.3 \%)$ & 0.032 \\
\hline Arteriovenous fistula & - & $1(0.7 \%)$ & - & 0.379 \\
\hline Convertion to open surgery & $2(0.9 \%)$ & - & - & 0.343 \\
\hline Intensive care follow-up & - & $1(0.7 \%)$ & - & 0.379 \\
\hline *p<0.005 & & & & \\
\hline
\end{tabular}

entry in 110 patients and reported that the overall complication rate was $11.8 \%$. In 10 patients, hydrothorax/hemothorax, in one patient - perinephric collection, in two patients - infection/sepsis and in 2, massive bleeding were observed. As a result, they have reported high success rates in selected patients with acceptable morbidity. In a study of 597 cases published in 2011 by Mousavi et al. (21) investigating the complication rate of supracostal and infracostal entry in 123 patients, total complication rate and the rate of perioperative bleeding as the most common complication were reported to be $13 \%$ and $5.7 \%$, respectively. In supracostal access applications, the incidence of complications requiring intervention, such as pleural effusion and pneumothorax ranges from $12 \%$ to $4 \%(22,23)$. Intrathoracic complication rate has been reported to increase when entry was done over the $11^{\text {th }}$ rib compared to that over the $12^{\text {th }}$ rib $(1.4 \%$ versus 34.6\%) (24). Mousavi-Bahar et al. (21) has reported the pneumothorax rate as $2.4 \%$. These results show that supracostal entry should not be done unless required. In a study of 318 cases published in 2011 by Honey et al. (25) that examined the complication of supracostal and infrakostal access, the total complication rate, independent from tract enty, was reported to be $11.6 \%$. Pleural complication rate was reported to be $3.2 \%$ in supracostal entry application although even higher than literature. $(p=0.038)$. However, in the same study, it was reported that in patients undergoing infracostal puncture febrile infection as complication was observed more frequently with the rate of $5.6 \%(p=0.043)$.

In this study, similar to the literature, pulmonary complications occurred most often in supracostal entry cases with a rate of $8.3 \%$ $(p=0.032)$. Likewise, febrile complication rates were more frequently observed in infracostal entry with a rate of $11.4 \%(p=0.326)$, though not significant (Table 6). In subjects who underwent supracostal entry, no perirenal bleeding and severe hematuria were seen $(p=0.891)$. Our study also appears to support the reliability and minimal morbidity of supracostal entry, as (because of) pleural injury risk for supracostal entry seems to be low. Despite less number of subjects, we believe that our complication rate was in parallel with the literature data.

While trying to treat urinary tract stone disease, causing death is the most feared complication. The rate of mortality after PCNL was reported to be $0 \%$ to $0.3 \%$ in the 2013 EAU guideline (26). A few cases of death occurring after bleeding have been reported in the published first series (6). Although Segura et al. (27) reported no cases of deaths in their study of 1.000 PCNL cases published in 1985, in the series issued in 1987 by Lee et al. (6), 1 (0.2\%) death due to respiratory failure in a patient with previous lung disease and other $1(0.2 \%)$ death due to acute myocardial infarction were reported.

Although CDCSC was used in several studies in the field of general surgery, in those related to urology was used only in retroperitonoscopy, laparoscopic radical prostatectomy and laparoscopic live donor nephrectomy $(28,29,30)$. Attempting to classify the PCNL complications according to the CDCSC is based on the very near future.

Although CDCSC brings standardization to the rating of postoperative complications, when placed in the urology practice, it seems to have some limitations. In the world of urology, creating a novel classification system that can cover urological operations might be more beneficial or CDCSC can be revised slightly to strictly include complications after urological operations.

\section{Study Limitations}

The factors that limit our study were the electively good evaluation of patients, not to use multiple tract entrance, and though the main goal was to achieve stone-free status, the limited number of complications we have seen compared to the number of cases. The second limitation of this study was that although there was not an exact age cutoff point in the literature to make the differentiation between young and old, we tried to overcome this issue by using the classification system used in the study of Koppie et al. (7).

\section{Conclusion}

In this series, the remarkable feature is that about 50\% of patients had various comorbidities. Advanced age and comorbidity makes patients more susceptible to surgical complications. In this study, achieving similar complication rate between the groups suggests that the presence of preoperative comorbidities do not create a major risk for complications after PCNL. Further studies with larger samples and multiple tract entry are warranted.

\section{Ethics}

Ethics Committee Approval: The study were approved by the Bülent Ecevit University of Local Ethics Committee (Date: 16/04/2013, meeting no: 2013/09), Informed Consent: Consent form was filled out by all participants.

Peer-review: Internal peer-reviewed.

\section{Authorship Contributions}

Surgical and Medical Practices: Reha Girgin, Bülent Akduman, Concept: Bülent Akduman, Reha Girgin, Design: Bülent Akduman, Reha Girgin, Data Collection or Processing: Reha Girgin, Analysis or Interpretation: Reha Girgin, Ramazan Topaktaş, Literature Search: Selçuk Altın, Ali Akkoç, Writing: Reha Girgin, Cemil Aydın. 
Conflict of Interest: No conflict of interest was declared by the authors.

Financial Disclosure: The authors declared that this study has received no financial support.

\section{References}

1. Menon M, Resnick MI. Urinary Lithiasis: etiology, diagnosis, and medical management. Campbell's Urology, 8th ed. Philadelphia, Saunders, 2002.

2. Turk C, Knoll T, Petrik A, Sarica K, Straub M, Seitz C. Guidelines on urolithiasis. Eur Assoc Urol 2010:1-106.

3. Labate $G$, Modi $P$, Timoney $A_{1}$ Cormio L, Zhang $X_{1}$ Louie $M$, Grabe $M_{1}$ Rosette On Behalf Of The Croes Pcnl Study Group J. The percutenous nephrolitotomy global study: Classification of complications. J Endourol 2011;25:1275-1280.

4. Paik ML, Resnick MI. Is there a role for open stone surgery? Urol Clin North Am 2000;27:323-331.

5. Michel MS, Trojan L, Rassweiler JJ. Complications in percutaneous nephrolithotomy. Eur Urol 2007;51:899-906.

6. Lee WJ, Smith AD, Cubelli V, Badlani GH, Lewin B, Vernace F, Cantos E. Complications of percutaneous nephrolithotomy. AJR Am J Roentgenol 1987;148:177-180.

7. Koppie TM, Serio AM, Vickers AJ, Vora K, Dalbagni G, Donat SM, Herr $\mathrm{HW}$, Bochner BH. Age-adjusted Charlson comorbidity score is associated with treatment decisions and clinical outcomes for patients undergoing radical cystectomy for bladder cancer. Cancer 2008;112:2384-2392.

8. Dindo D, Demartines N, Clavien PA. Classification of surgıcal complications: a new proposal with evaluation in a cohort of 6336 patients and results of a survey. Ann Surg 2004;240:205-213.

9. Segura JW. Percutaneous Nephrolithotomy: Technique, indications, and complications. AUA Guidelines 1993;12:154.

10. Charlson ME, Pompei $P$, Ales KL, MacKenzie CR. A new method of classifying prognostic cormorbidity in longitudinal studies: development and validation. J Chronic Dis 1987:40:373-383.

11. Tonner PH, Kampen J, Scholz J. Pathophysiological changes in the elderly. Best Practi Res Clin Anaesthesiol 2003;17:163-177.

12. $\mathrm{Ng} \mathrm{CF}$. The effect of age on outcomes in patients undergoing treatment for renal stones. Curr Opin Urol 2009;19:211-214.

13. Stoller ML, Bolton $D_{1}$ St Lezin $M$, Lawrence $M$. Percutaneous nephrolithotomy in the elderly. Urology 1994;44:651-654.

14. Sahin A, Atsü N, Erdem $E_{1}$ Oner $S$, Bilen $C$, Bakkaloğlu $M$, Kendi S. Percutaneous nephrolithotomy in patients aged 60 years or older. J Endourol 2001;15:489-491.

15. Okeke Z, Smith AD, Labate G, D'Addessi A, Venkatesh $R$, Assimos D, Strijbos WE, de la Rosette JJ; CROES PCNL Study Group. Prospective comparison of outcomes of Percutaneous nephrolithotomy in elderly patients versus younger patients. J Endourol 2012;26:996-1001.
16. Unsal A, Resorlu B, Atmaca AF, Diri A, Goktug HN, Can CE, Gok B, Tuygun $C$, Germiyonoglu $C$. Prediction of morbidity and mortality after percutaneous nephrolithotomy by using the charlson comorbidity Index. Urology 2012;79:55-60.

17. Oner $S$, Okumus $M M$, Demirbas $M$, Onen $E$, Aydos $M M$, Ustun $M H_{1}$ Kilic $M$, Avci S. Factors influencing complications of percutaneous nephrolithotomy: a single-center study. J EndoUrol 2015;12:2317-2323.

18. Olvera-Posada D, Tailly $T$, Alenezi $H$, Violette PD, Nott $L$, Denstedt JD, Razvi H. Risk Factors for Postoperative Complications of Percutaneous Nephrolithotomy at a Tertiary Referral Center. J Urol 2015;194:1646-1651.

19. Hopper KD, Yakes WF. The posterior intercostal approach for percutaneous renal procedures: risk of puncturing the lung, spleen and liver as determined by CT: AJR Am J Roentgenol 1990;154:115-117.

20. Sukumar S, Nair B, Ginil KP, Sanjeevan KV, Sanjay BH. Supracostal access for percutaneous nephrolithotomy: less morbid, more effective Int Urol Nephrol 2008;40:263-267.

21. Mousavi-Bahar SH, Mehrabi S, Moslemi MK. The safety and efficacy of PCNL with supracostal approach in the treatment of renal stones. Int Urol Nephrol 2011;43:983-987.

22. McDougall EM, Liatsikos EN, Dinlenc CZ, Smith AD. Percutaneous approaches to the upper urinary tract. In: Walsh $P C$, Retik $A B$, Vaughan ED Jr, Wein AJ (eds). Campbells urology, 8th ed. Philadelphia, Saunders, 2002, pp 3320-3360.

23. Golijanin D, Katz R, Verstandig A, Sasson T, Landau EH, Meretyk S. The supracostal percutaneous nephrostomy for treatment of staghorn and complex kidney stones. J Endourol 1998;12:403-405.

24. Munver $R$, Delvecchio FC, Newman GE, Preminger GM. Critical analysis of supracostal access for percutaneous renal surgery. J Urol 2001;166:1242-1246.

25. Honey RJ, Wiesenthal JD, Ghiculete D, Pace S, Ray AA, Pace KT. Comparison of supracostal versus infracostal percutaneous nephrolithotomy using the novel prone-flexed patient position. J Endourol 2011;25:947-954.

26. Türk C, Knoll T, Petrik A, Sarica K, A. Skolarikos, Straub M, Seitz C. Guidlines on Urolithiasis. EUA 2013:36.

27. Segura JW, Patterson DE, LeRoy AJ, Williams HJ Jr, Barrett DM, Benson RC $J r$, May GR, Bender CE. Percutaneous removal of kidney stones: review of 1,000 cases. J Urol 1985;134:1077-1081.

28. Rassweiler JJ, Sugiano M, Hruza M, Tefekli A, Stock C, Teber D. Retrograde nevre sparing (NS) laparoscopic radical prostatectomy (LRP): Technical aspects and early results. Eur Urol Suppl 2006;5:925-933.

29. Kocak B, Koffron AJ, Baker TB, Salvalaggio PR, Kaufman DB, Fryer $J P$, Abecassis MM, Stuart FP, Leventhal JR. Proposed classification of complications after live donor nephrectomy. Urology 2006;67:927-931.

30. Gonzalgo ML, Pavlovich CP, Trock BJ, Link RE, Sullivan W, Su LM. Classification and trends of perioperative morbidities following laparoscopic radical prostatectomy. J Urol 2005;24:88-93. 